\title{
STUDENTS' PROBLEMS IN ANSWERING LISTENING SECTION OF TOEFL AT NON ENGLISH STUDY PROGRAM OF UPN VETERAN JAKARTA
}

\author{
${ }^{1}$ Cut fitariana, ${ }^{2}$ Abdul Rohim \\ 1 UPN Veteran Jakarta \\ cutfitariana@upnvj.ac.id \\ ${ }^{2}$ Universitas Muhammadiyah Tangerang \\ abdulrohim2013@yahoo.com
}

\begin{abstract}
This research aimed to find the problems that students did in answering TOEFL especially in listening section. The research used descriptive qualitative approach. For the data collection, it used the instrument is interview. The subjects of the research were non english department students in seventh grade of FIKES Universitas Pembangunan Nasional Veteran Jakarta. To analyze the data, it was through the techniques: data collection, data display, data reduction, and conclusion drawing. 25 seventh semester students of Nursing Study Program participated in this study selected by using random sampling techniques. Descriptive qualitative method was used in this research. The results of this research indicate that the difficulties experienced by students based on the the interview are difficultiy in their concentration while listening, difficulty regarding vocabulary meaning, difficulty in catching meaning in long and speed conversation, and difficulty in recognizing unfamiliar topic.
\end{abstract}

Key words: Problem, Listening, TOEFL.

\section{INTRODUCTION}

In the industrial revolution 5.0, English is an important tool for communication for everyone, because it is an international language, which is used in all over the world. In Indonesia, English has become one of the cumpolsory subjects in the education that consists of four skills, currently the TOEFL test is the most internationally recognized test for measuring a person's level of English (Warfield, et.al, 2013). And also has been mentioned by Phillips (2001, p. 25). The TOEFL is a test to measure the English proficiency of non-native speakers of English||. One of them is listening. To measure whether the students master in English or not, the test of English - Language proficiency is needed. There are several kind of English-Language test, one of them is TOEFL (Test of English as a Foreign Language) test. TOEFL is an important test which impacts student's career, and it is designed to measure non-native speaker's ability in mastering English language.

Recently, in Indonesia, where English is a foreign language, TOEFL has been taught in many places, one of them is in University. Several universities in Indonesia, especially in Jakarta, require their students to have a TOEFL score of at least 500 for students of English program and 475 for students non-English program and even they are expected to achieve the score as one of the requirements for graduation of undergraduate candidates on their universities. 
Globish (An English-Indonesian journal for English, Education and Culture

Vol. 10, No.2, July 2021,

P-ISSN: 2301-9913, E-ISSN: 2597-9132

DOI: http://dx.doi.org/10.31000/globish.v7i2

Therefore, by this phenomenon, many universities provide a TOEFL course or it even has been taught in one semester in their classes. As what happened in Universitas Pembangunan Nasional Veteran Jakarta (UPNVJ).

TOEFL has been taught in several faculties in UPNVJ either in a course system or in course credits (SKS) in one semester. Students will be presented with some sections of TOEFL in general such as listening comprehension section, structure and written expression section, reading comprehension section, and writing essay. They will also learn many topics and subtopics related to those sections. The book used in learning TOEFL course is by Phillips (2004) entitled "Longman Introductory Course for the TOEFL Test." The book consists of three parts listening section; part A (short dialogue), part B (conversation) and part C (talks). Structure and written expression, and Reading comprehension.

The TOEFL class runs for one semester that consist of seven meetings before mid term test (UTS) and seven meetings before the final test (UAS) and the students will be tested in the mid term test and the final test, they will be tested for twice in total. It is common to get some problems after the test because the questions in TOEFL test are challenging. There are three sections in the TOEFL test, they are listening comprehension (Part I), Structure and written expression (Part II), and Reading comprehension (Part III).

In taking the TOEFL class, students may fell the difficulties that can affect the TOEFL test results. In order to find out which part of the TOEFL test is difficult for students, the researchers conducted a pre-research in their class on nursing students at UPNVJ. Based on the pre-research, the researchers found out that some students find it difficult to do listening comprehension section compared to the other sections. Due to that fact, this research focuses on the listening comprehension section. Therefore, the researchers are interested in analyzing students' problems in answering listening section of TOEFL at non english study program of UPN Veteran Jakarta. The researchers want to conduct the research entitled - STUDENTS' PROBLEMS IN ANSWERING LISTENING SECTION OF TOEFL AT NON ENGLISH STUDY PROGRAM OF UPN VETERAN JAKARTA.

\section{THEORITICAL FRAMEWORK}

\section{Skills tested in Listening Comprehension}

Listening has been defined by many researchers. Chastain (1971) defined listening as the ability to understand native speech at normal speed. Morley (1972) said listening involves auditory discrimination, aural grammar, selecting necessary information, remembering it, and connecting it to the process between sound and form of meaning. According to Postovsky (1975), listening differs in meaning from sound discrimination to aural comprehension. Goss (1982) defined listening as a process of understanding what is heard and organizing it into lexical elements to which meaning can be allocated Listening is the ability to identify and understand what others are saying. This involves understanding a speaker's accent or 
Globish (An English-Indonesian journal for English, Education and Culture

Vol. 10, No.2, July 2021,

P-ISSN: 2301-9913, E-ISSN: 2597-9132

DOI: http://dx.doi.org/10.31000/globish.v7i2

pronunciation, his grammar and his vocabulary, and grasping his meaning (Howatt and Dakin 1974).

In section in TOEFL test is listening comprehension section. The purpose of the listening section is to assess the ability to comprehend spoken English. There are three parts to the listening section: Part A, with short dialogues containing 30 questions, Part B with longer dialogues consisting of 8 questions, and part $\mathrm{C}$, a lecture with 12 questions. In all parts of these sections, the conversations and dialogues are not played for second times so that test takers need to listen to the recordings very carefully and attentively. Then, they choose one of four possible answers for each of the 50 questions. The time allotted for the listening section is 30 to 35 minutes (Pyle \& Page, 2002, p. 1).

According to Phillips (2004) in Longman Introductory Course for the TOEFL® Test, the researchers found there are 12 listening skills discussed and tested in TOEFL listening comprehension section and some strategies to answer the test.

From 12 skills tested in Listening Comprehension section, there 6 skills are common found in short dialogues, 6 skills appear in long conversations and long talks. The skills tested in long conversation are the same skills tested in long talks. In short, the test takers have to master 12 listening comprehension skills to ease them in answering the questions. Listening comprehension section skills tested will be discussed below.

The first section of the TOEFL test is the Listening Comprehension section. On the computer TOEFL test, the first section is called the Listening section. This section consists of thirty to fifty questions. In this section, you will listen to recorded material. look at visual cues, and respond to various types of questions about the material. You must listen carefully because you will hear the recorded material oue time only and the recorded material does not appear on the computer screen. Be familiar with the directions. The directions on every paper TOEFL test are the same. so it is not necessary to spend time reading the directions carefully when you take the test. You should be completely familiar with the directions before the day of the test.

In listening part A consist of two- to four-line dialogues between two speakers. Each dialogue is accompanied by a context-setting visual and is followed by one multiple choice question. You will listen to each short dialogue as you see a context-setting visual on the screen. Then you will listen to a question as you see the question and four answer choices on the screen. The eleven to seventeen short dialogues and questions about them make up Part A on the computer TOEFL test that consists of restatements, negatives, suggestions, passives, conclusion about who dan where, and expression of agreement.

In listening part B of the Listening Comprehension section of the paper TOEFL test consists of two long conversations, each followed by a number of questions. You will hear the conversations and the questions on a recording; they are not written in your test book. You must choose the best answer to each question from the four choices that are written in your test book. The conversations are often about some aspect of school (how difficult a class is, how 
Globish (An English-Indonesian journal for English, Education and Culture

Vol. 10, No.2, July 2021,

P-ISSN: 2301-9913, E-ISSN: 2597-9132

DOI: http://dx.doi.org/10.31000/globish.v7i2

to write a research paper, how to register for a course) or about general living (renting an apartment, playing sports, going to the bank). The conversations can also be about topics currently in the news in the United States (desalination of the water supply, recycling of used products, damage from a storm or some other type of natural phenomenon).

In listening part $\mathrm{C}$ of the Listening Comprehension section of the paper TOEFL test consists of three long talks, each followed by a number of questions. You will hear the talks and the questions on a recording; they are not written in your test book. You must choose the best answer to each question from the four choices that are written in your test book. Like the conversations in Listening Part B, the talks are often about some aspect of school life or topics currently in the news. It is also very common for the talks to be shortened versions of lectures from courses taught in American colleges and universities.

Here are general strategies in answering TOEFL test:

1. Listen carefully to the passages. You should concentrate fully on what the speakers are saying on the recording because you will hear the recording one time only.

2. Know where the easier and the more difficult questions are generally found. Within each part of the Listening Comprehension section on the paper test. the questions generally progress from easy to difficult.

3. Be familiar with the pacing of the test. You have twelve seconds between each question on the recording. so you must answer each question within twelve seconds and then be prepared for the next question on the recording.

4. Never leave any answers blank on your answer sheet. Even if you are not sure of the correct response. you should answer each question. There is no penalty for guessing.

5. Use any remaining time to look ahead at the answers to the questions that follow. When you finish with one question. you may have time to look ahead at the answers to the next question.

\section{RESEARCH METHODOLOGY}

The research method used in this study is a qualitative method, which aims to analyze the difficulties experienced by high scool students in answering reading comprehension questions on the TOEFL test. For the data collection, it used the interview. The subjects of the research were non english department students in seventh grade of FIKES UPNVJ. To analyze the data, it was through the techniques: data collection, data display, data reduction, and conclusion drawing. 25 seventh semester students of Nursing Study Program participated in this study selected by using random sampling techniques. With the procedure of collecting data through interviews related to the problems that faced by them in answering TOEFL test specifically in the listening section.. 


\section{RESEARCH FINDING AND DISCUSSION}

\section{Research Finding}

As stated in chapter three the instrument of this research is interview. Through that instrument the researcher got the answer of the research problems - what is the problems faced by students' in answering listening section of TOEFL

From the interview the researcher found out some problems faced by the students' in answering TOEFL. In the listening section there are three parts of the questions, part A short dialogues, part B long conversations and part $C$ long talks. The problems found are:

\section{1) Lack of vocabulary.}

\section{Student 06}

"Pada saat menjawab soal-soal TOEFL faktor kesulitan yang saya hadapi adalah kurangnya kosa kata yang saya miliki sehingga banyak dari teks dan soal yang tidak saya pahami, baik itu di bagian listening comprehension"

\section{Student 09}

"Lumayan susah banget vocabnya, apalagi buat sy yang bukan jurusan bahasa inggris"

\section{Student 16}

"Aduh gak familiar dan jarang denger kosakata baru, jadi itu sih yang menurut saya susah dalam menjawab listening"

\section{2) Lack of concentration}

\section{Student 01}

"Menurut sy sih yang partpart C itu susah sehingga itu mengakibatkan saya kurang konsentrasi dan mengantuk saat menjawab part itu".

\section{Student 10}

"sering ngeblank sendiri sih, gak konsen, jadi kacau deh pas ngerjain soal."

\section{3) Unclear pronunciation}

\section{Student 04}

"Perbedaan pengucapan menjadikan kesulitan tersediri buat saya. Kadang- kadang ada yang sama pengucapannya, pokoknya buat bingung deh." 
Globish (An English-Indonesian journal for English, Education and Culture

Vol. 10, No.2, July 2021,

P-ISSN: 2301-9913, E-ISSN: 2597-9132

DOI: http://dx.doi.org/10.31000/globish.v7i2

\section{Student 25}

"Soal yang paling sulit saya rasakan ada di bagian listening comprehension karena saya tidak memahami apa yang diucapkan oleh speaker padahal hampir semua possible answer sudah ada di lembar soal"

\section{4) Unfamiliar topic in listening.}

\section{Student 07}

"Kadang yang membuat saya susah adalah adanya topik yang gak saya ketahui, jadi membuat saya bingung."

\section{Student 18}

"Saya anak kesmas, tapi topiknya tentang komputer, nah itu yang bikin saya gak ngerti."

\section{Student 22}

"Sangat sulit memahami topik yang dibicarakan di listening comprehension bu, sehingga saya tidak dapat menjawab soal dengan tepat."

\section{Discussion}

Here the discussion based on the interview data, the researchers found that there were some factors that make students faced difficulties in answering TOEFL test of listening comprehension.

The first, vocabulary is basic component non only in english language but also in other language. TOEFL is the test of english, the test that measure english proficiency. To master the language, the students have to master the basic english component, such as vocabularies and grammar. In this case some of the students stated that don't have enough vocabularies, so they answer the TOEFL difficultly. In listening to the TOEFL test unfamiliar vocabulary is commonly appear which make students face difficulty to answer the TOEFL test question. Related to the listening comprehension, the students find out the unfamiliar vocabulary that makes them confused to comprehend the information. Not only new vocabulary but also they agreed that they hear similar sound of vocabulary but different in meaning.

Second one, lack of concentration. It is not very easy for listeners to concentrate on the listening text. Based on the students' experience during taken the TOEFL test they agreed that they cannot stay to focus on answering the question of TOEFL test while they are listening. The problem is because of the noisy from the outside like construction sound from another building that can distract their concentration. In addition, students also lose their concentration because of others students' activity.. It will make them stressed and uninterested anymore to continue the listening test process. As a result, lack of concentration could not be denied as a big problem of the students. The reason was that listening required high concentration, and might affect their motivation in learning. The loss of concentration could obstruct the studentsto follow the lessons well. Therefore, concentration during listening was considered as something matter to keep the students being focused. 
Globish (An English-Indonesian journal for English, Education and Culture

Vol. 10, No.2, July 2021,

P-ISSN: 2301-9913, E-ISSN: 2597-9132

DOI: http://dx.doi.org/10.31000/globish.v7i2

Third one, speed of listening. It is very difficult for non english students to listen more than five minutes long and complete the listening tasks. Listening to the long speech or conversation then followed by some questions is commonly made students feel confused to answer the question. The reason is they easily forget the information given especially if it given delivered with native speaker who speaks too fast. The students have to memorize the information given in their mind then complete the question after that. It can meke them feel difficulties, it will be difficult to them to comprehend information which given in long speech and speed delivery too fast. Those problems will make them failed to comprehend information and answered listening section in the TOEFL test question.

The last one, unfamiliar topic in listening. when listening texts contain known topic or field of study those are very familiar for them it would be very easy for students to answer the listening section. If students know well about the topic this can arouse their interest and motivation and can have a positive impact on the students' listening comprehension ability. However, a lot of topics in listening section have more than one differnt topics and if they are not used appropriately in their appropriate contexts students will get confused.

According to those discussions above, the researcher concluded that some of the students did not know the strategies in answering TOEFL. In one of TOEFL book, Longman Introductory Course for the TOEFL stated there are alot of one strategies in answering TOEFL test.

\section{CONCLUSION AND SUGGESTION}

The researchers made conclusions from the result of the research as follows : There are four problems that students faced in answering TOEFL test, especially in listening comprehension section that consistsof three parts. The results of this research showed that the difficulties experienced by students based on the the interview are problem regarding vocabulary meaning, their concentration while listening, problem in catching meaning in long and speed conversation, and problem in recognizing unfamiliar topic.

Finally, the researchers hope this research will be useful for the test takers, teachers. It is very necessary to give some valuable information for students who will take TOEFL test who are expected to understand what skill will be tested in TOEFL and know where they are lack in. In addition, the researchers suggest to the next researchers when they want to conduct the same discussion about TOEFL test. It is better for them to expand the research into other section of TOEFL test.

\section{REFERENCES}

Chastain, K. (1971). The Development of Modern Language Skills: Theory to Practice. Philadelphia: Center for Curriculum Development

Goss, B. (1982). Listening as Information Processing. Communication Quarterly, 30, 304-307. http://dx.doi.org/10.1080/01463378209369465 
Globish (An English-Indonesian journal for English, Education and Culture

Vol. 10, No.2, July 2021,

P-ISSN: 2301-9913, E-ISSN: 2597-9132

DOI: http://dx.doi.org/10.31000/globish.v7i2

Howatt, A. and J. Dakin. 1974. Language laboratory materials, ed. J. P. B. Allen, S. P. B. Allen, and S. P. Corde

Morley, J. (2001). Aural Comprehension Instruction: Principles and Practices. In M. Celce-Murcia (Ed.), Teaching English as a Second or Foreign Language (pp. 69-85) Boston: Heinle and Heinle.

Phillips, D. (2004). Longman Introductory Course for the TOEFL: Preparation for the Computer and Paper Test. New York: Pearson Education.

Postovsky, V. A. (1975). On Paradoxes in Foreign Language Teaching. Modern Language Journal, 59(1), 18-21. http://dx.doi.org/10.2307/325442

Pyle, M. A. (2002). TOEFL Preparation Guide: Test of English as a Foreign Language. New Delhi: Wiley Dreamtech India (P) Ltd.

Warfield, W., Laribee, R., \& Geyer, R. W. (2013). Examining results and establishing benchmark data from the TOEFL ITP test. American Academic \& Scholarly Research Journal, 5(3), 191-198. 